Supporting Information for

\title{
Hyperbranched Macromolecules via Olefin Metathesis
}

\author{
Irina A. Gorodetskaya and Robert H. Grubbs \\ Arnold and Mabel Beckman Laboratories of Chemical Synthesis, Division of Chemistry and \\ Chemical Engineering, California Institute of Technology, Pasadena, California 91125
}

\section{Table of Contents}

1) Materials and Instrumentation $\quad$ S2

2) Representative procedure for addition of acrylates (synthesis of 2) S2

3) Reaction schemes and experimental procedures (with full characterizations) for 3-7 $\quad$ S3

4) Representative olefin cross metathesis polymerization procedure (4a) S9 with a comment on polymerization conditions and sample SEC traces $\quad$ S10

5) Explanation of ${ }^{1} \mathrm{H}$ NMR spectra of 4 (Figure 1) $\quad$ S11 
Materials and Instrumentation. All reagents were purchased from Aldrich at the highest available purity grade and used without further purification. NMR spectra were obtained using a Varian Mercury-300 spectrometer; samples were dissolved in (methylene chloride)- $\mathrm{d}_{2}$. Size exclusion chromatography (SEC) analysis was performed using a Wyatt triple detector system equipped with a refractive index (Optilab rex) detector, a viscometer (ViscoStar) detector, and a triple angle light scattering (miniDAWN TREOS, with laser wavelength of 658 $\mathrm{nm}$ ) detector all operating at $25^{\circ} \mathrm{C}$. Viscotek ViscoGEL I-Series (one mixed bed medium MW and one mixed bed high MW) columns were used for SEC with THF as the eluent and a Shimadzu LC-10AD pump operating at $1 \mathrm{~mL} /$ minute.

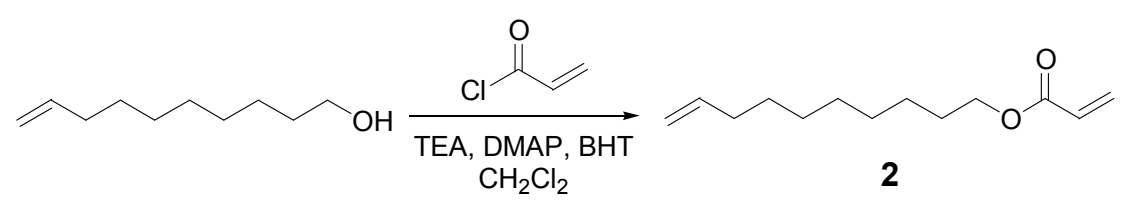

Scheme S1. Synthesis of monomer 2.

\section{Representative procedure for the addition of acryloyl chloride to alcohol groups (2).}

Acryloyl chloride $(0.8 \mathrm{~mL}, 9.6 \mathrm{mmol})$ was slowly added via syringe to a stirring solution of 9decene-1-ol (1 g, $6.4 \mathrm{mmol})$ and triethylamine (TEA) $(2.2 \mathrm{~mL}, 16 \mathrm{mmol})$ in dry THF $(2 \mathrm{~mL})$ at 0 ${ }^{\circ} \mathrm{C}$ (Scheme S1). After the solution was allowed to warm to room temperature, a catalytic amount of 4-(dimethylamino)pyridine (DMAP) $(3.9 \mathrm{mg}, 0.06 \mathrm{mmol})$ was added, and the flask was stirred for an additional $2 \mathrm{~h}$. The reaction mixture was then filtered, and the solvent was removed under reduced pressure. The crude product was purified by silica gel (TSI) chromatography, eluting with 95:5 hexane:ethyl acetate to afford $0.99 \mathrm{~g}$ (73\% yield) of a viscous colorless oil 2. ${ }^{1} \mathrm{H}$ NMR (300MHz, $\left.\mathrm{CD}_{2} \mathrm{Cl}_{2}, \mathrm{ppm}\right): \delta 6.36(\mathrm{dd}, \mathrm{J}=17.5 \mathrm{~Hz}, \mathrm{~J}=1.6 \mathrm{~Hz}, 1 \mathrm{H}), 6.11$ 
$(\mathrm{dd}, \mathrm{J}=17.5 \mathrm{~Hz}, \mathrm{~J}=10.2 \mathrm{~Hz}, 1 \mathrm{H}), 5.89-5.75(\mathrm{~m}, 1 \mathrm{H}), 5.80(\mathrm{dd}, \mathrm{J}=10.2 \mathrm{~Hz}, \mathrm{~J}=1.6 \mathrm{~Hz}, 1 \mathrm{H})$, 5.03-4.89 (m, 2H), $4.12(\mathrm{t}, \mathrm{J}=6.9 \mathrm{~Hz}, 2 \mathrm{H}), 2.04(\mathrm{~m}, 2 \mathrm{H}), 1.65(\mathrm{~m}, 2 \mathrm{H}), 1.31(\mathrm{~m}, 10 \mathrm{H}) .{ }^{13} \mathrm{C}$ NMR (300MHz, $\left.\mathrm{CD}_{2} \mathrm{Cl}_{2}, \mathrm{ppm}\right): \delta 166.62,139.81,130.58,129.27,114.42,65.15,34.35,29.91$, 29.77, 29.61, 29.49, 29.17, 26.47. $\operatorname{HRMS}(\mathrm{EI}+) \mathrm{m} / z: 210.1617\left[_{\mathrm{M}}^{+\bullet}\right.$.

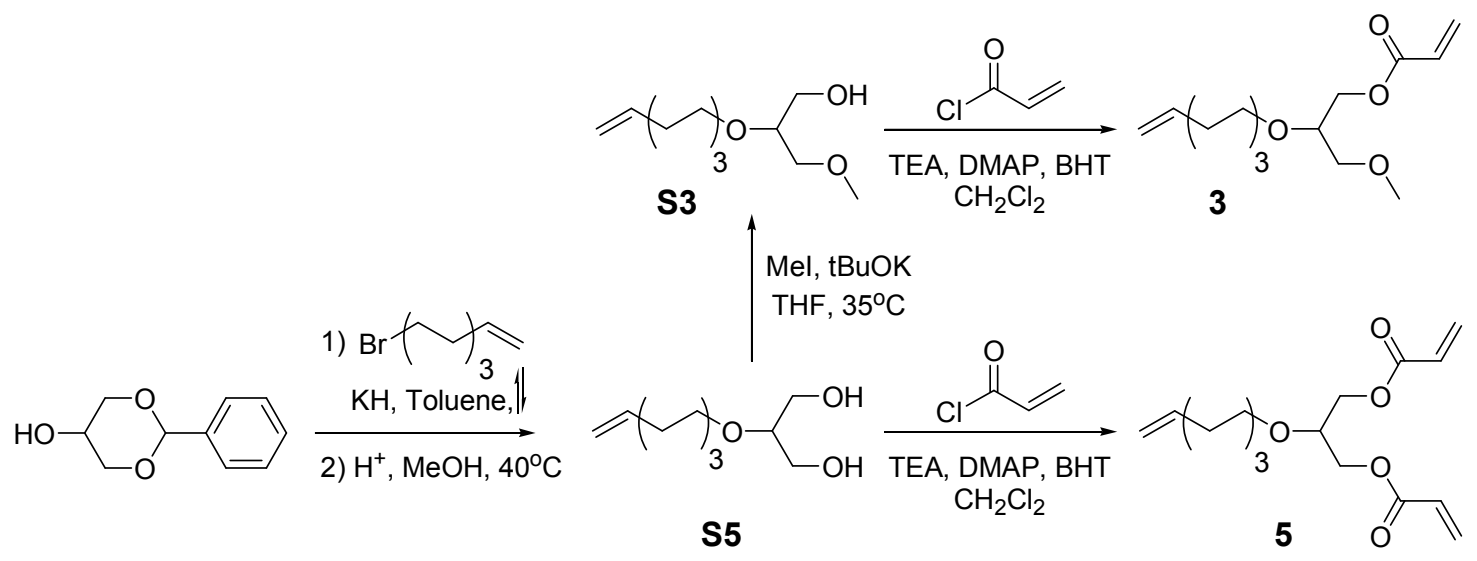

Scheme S2. Synthesis of monomers 3 and 5.

(3). Monomer $\mathbf{3}$ was derived from the same starting material as $\mathbf{5}$ (see synthesis of $\mathbf{5}$ below). The intermediate S5 (Scheme S2) was treated with 0.5 equivalents of both MeI and $\mathrm{tBuOK}$ in $\mathrm{THF}$ at $35^{\circ} \mathrm{C}$ for $10 \mathrm{~h}$. The unreacted base was then neutralized with $\mathrm{tBuOH}$, and the reaction mixture was concentrated and purified by silica gel chromatography (4:1 hexane:EtOAc). A clear viscous oil S3 was produced in 54\% yield. ${ }^{1} \mathrm{H}$ NMR $(300 \mathrm{MHz}$, $\left.\mathrm{CD}_{2} \mathrm{Cl}_{2}, \mathrm{ppm}\right): \delta 5.82(\mathrm{~m}, 1 \mathrm{H}), 5.03-4.90(\mathrm{~m}, 2 \mathrm{H}), 3.67-4.41(\mathrm{~m}, 7 \mathrm{H}), 3.33(\mathrm{~s}, 3 \mathrm{H}), 2.28($ broad $\mathrm{s}, 1 \mathrm{H}), 2.04(\mathrm{~m}, 2 \mathrm{H}), 1.55(\mathrm{~m}, 2 \mathrm{H}), 1.34(\mathrm{~m}, 6 \mathrm{H}) .{ }^{13} \mathrm{C} \mathrm{NMR}\left(300 \mathrm{MHz}, \mathrm{CD}_{2} \mathrm{Cl}_{2}, \mathrm{ppm}\right): \delta 139.73$, $114.47,79.03,73.10,70.69,63.09,59.56,34.28,30.60,29.50,29.44,26.48$. HRMS(FAB+) $m / z$ : $217.1813[\mathrm{M}+\mathrm{H}]^{+}$. 
Colorless oil 3 (Scheme S2) was made from S3 according to the representative procedure outlined for 2 in $79 \%$ yield. ${ }^{1} \mathrm{H}$ NMR $\left(300 \mathrm{MHz}, \mathrm{CD}_{2} \mathrm{Cl}_{2}, \mathrm{ppm}\right): \delta 6.38$ (dd, J=17.1 Hz, J $=1.8$ $\mathrm{Hz}, 1 \mathrm{H}), 6.14(\mathrm{dd}, \mathrm{J}=17.4 \mathrm{~Hz}, \mathrm{~J}=10.5 \mathrm{~Hz}, 1 \mathrm{H}), 5.89-5.75(\mathrm{~m}, 1 \mathrm{H}), 5.84(\mathrm{dd}, \mathrm{J}=10.2 \mathrm{~Hz}, \mathrm{~J}=$ $1.8 \mathrm{~Hz}, 1 \mathrm{H}), 5.02-4.89(\mathrm{~m}, 2 \mathrm{H}), 4.25(\mathrm{dd}, \mathrm{J}=11.4, \mathrm{~Hz}, \mathrm{~J}=4.3 \mathrm{~Hz}, 1 \mathrm{H}), 4.13(\mathrm{dd}, \mathrm{J}=11.4, \mathrm{~Hz}, \mathrm{~J}$ $=5.7 \mathrm{~Hz}, 1 \mathrm{H}), 3.63$ (doublet of quintets, $\mathrm{J}=5.4 \mathrm{~Hz}, \mathrm{~J}=4.5 \mathrm{~Hz}, 1 \mathrm{H}), 3.53(\mathrm{t}, \mathrm{J}=6.6 \mathrm{~Hz}, 2 \mathrm{H})$, $3.44(\mathrm{~d}, \mathrm{~J}=4.8 \mathrm{~Hz}, 2 \mathrm{H}), 3.34(\mathrm{~s}, 3 \mathrm{H}), 2.04(\mathrm{~m}, 2 \mathrm{H}), 1.53(\mathrm{~m}, 2 \mathrm{H}), 1.42-1.27(\mathrm{~m}, 6 \mathrm{H}) .{ }^{13} \mathrm{C} \mathrm{NMR}$ (300MHz, $\left.\mathrm{CD}_{2} \mathrm{Cl}_{2}, \mathrm{ppm}\right): \delta 166.35,139.75,131.12,128.89,114.44,76.95,72.65,70.97,64.53$, 59.57, 34.28, 30.53, 29.48, 29.46, 26.43. HRMS(EI+) $m / z: 271.1907[\mathrm{M}+\mathrm{H}]^{+}$.

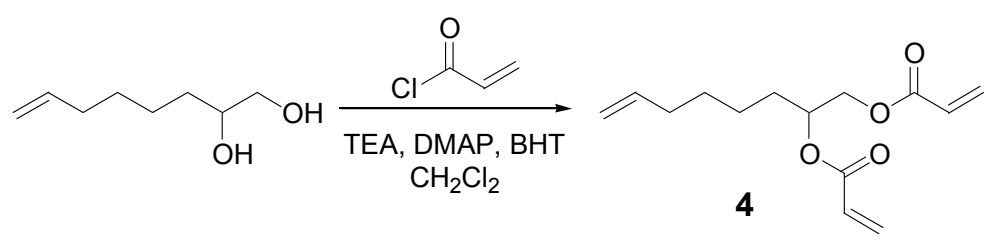

Scheme S3. Synthesis of monomer 4.

(4). Colorless oil 4 was prepared using the same procedure as described for 2 from 7octene-1,2-diol (Scheme S3) in 67\% yield. ${ }^{1} \mathrm{H}$ NMR (300MHz, $\left.\mathrm{CD}_{2} \mathrm{Cl}_{2}, \mathrm{ppm}\right): 6.37$ (ddd, J = 17.1 Hz, J = 4.2 Hz, J = 1.2 Hz, 2H), $6.11(\mathrm{ddd}, \mathrm{J}=17.1 \mathrm{~Hz}, \mathrm{~J}=10.5 \mathrm{~Hz}, \mathrm{~J}=2.7 \mathrm{~Hz}, 2 \mathrm{H}), 5.85-$ $5.73(\mathrm{~m}, 1 \mathrm{H}), 5.83(\mathrm{dd}, \mathrm{J}=10.5 \mathrm{~Hz}, \mathrm{~J}=1.8 \mathrm{~Hz}, 2 \mathrm{H}), 5.17(\mathrm{~m}, 1 \mathrm{H}), 5.05-4.91(\mathrm{~m}, 2 \mathrm{H}), 4.30$ (dd, $\mathrm{J}=12.0 \mathrm{~Hz}, \mathrm{~J}=3.6 \mathrm{~Hz}, 1 \mathrm{H}),(\mathrm{dd}, \mathrm{J}=12.0 \mathrm{~Hz}, \mathrm{~J}=6.5 \mathrm{~Hz}, 1 \mathrm{H}), 2.05(\mathrm{~m}, 2 \mathrm{H}), 1.65(\mathrm{~m}, 2 \mathrm{H})$, 1.43-1.36 (m, 6H). ${ }^{13} \mathrm{C}$ NMR (300MHz, $\left.\mathrm{CD}_{2} \mathrm{Cl}_{2}, \mathrm{ppm}\right): \delta 166.21,166.06,139.28,131.44$, $131.20,129.00,128.61,114.79,72.13,65.60,34.03,31.10,29.16,25.08 . \operatorname{HRMS}(\mathrm{EI}+) \mathrm{m} / z$ : $253.1441[\mathrm{M}]^{+\bullet}$.

(5). cis-1,3-O-Benzylideneglycerol (2 g, $11.1 \mathrm{mmol})$ was combined with potassium hydride (35\% suspension in oil, $2.5 \mathrm{~g}, 22.2 \mathrm{mmol}$ ) in $8 \mathrm{~mL}$ of toluene (Scheme $\mathrm{S} 2$ ) in a $50 \mathrm{~mL}$ 
round bottom flask equipped with a stir bar. The solution was stirred at room temperature until it had stopped fizzing, at which point 7-bromo-octene $(2 \mathrm{~mL}, 12.2 \mathrm{mmol})$ was slowly added to the reaction flask. The reaction was subsequently heated to reflux for $10 \mathrm{~h}$. The reaction mixture was then cooled to room temperature, and the unreacted potassium hydride was neutralized with a small amount of $\mathrm{iPrOH}$ before the solution was filtered and concentrated. The crude product was redissolved in $5 \mathrm{~mL}$ of methanol, a catalytic amount of pTsOH monohydrate was added, and the mixture was stirred at $40^{\circ} \mathrm{C}$ for $2 \mathrm{~h}$ (Scheme 2). Subsequently, the solution $\mathrm{pH}$ was adjusted to basic with $\mathrm{NaOH}$, and the solution was filtered before being concentrated and purified by silica gel chromatography. The product was eluted with 95:5 $\mathrm{CH}_{2} \mathrm{Cl}_{2}: \mathrm{MeOH}$ ) to give $1.20 \mathrm{~g}$ (53\% overall yield) of viscous colorless oil S5. ${ }^{1} \mathrm{H}$ NMR $\left(300 \mathrm{MHz}, \mathrm{CD}_{2} \mathrm{Cl}_{2}, \mathrm{ppm}\right): \delta 5.81$ (m, 1H), 5.02-4.89 (m, 2H), $3.64(\mathrm{~m}, 4 \mathrm{H}), 3.52(\mathrm{t}, \mathrm{J}=6.6 \mathrm{~Hz}, 2 \mathrm{H}), 3.41(\mathrm{~m}, 1 \mathrm{H}), 3.37(\mathrm{t}, \mathrm{J}=5.1 \mathrm{~Hz}$, 2H; OH), $2.04(\mathrm{~m}, 2 \mathrm{H}), 1.57(\mathrm{~m}, 2 \mathrm{H}), 1.34(\mathrm{~m}, 6 \mathrm{H}) .{ }^{13} \mathrm{C} \mathrm{NMR}\left(300 \mathrm{MHz}, \mathrm{CD}_{2} \mathrm{Cl}_{2}, \mathrm{ppm}\right): \delta$ $139.62,114.55,80.53,70.65,62.12,34.27,30.54,29.52,29.43,26.45 . \mathrm{HRMS}(\mathrm{EI}+) \mathrm{m} / z$ : $202.1569[\mathrm{M}]^{+\bullet}$.

Clear colorless oil $\mathbf{5}$ was made from S5 according to the representative procedure outlined for 2 (Scheme S2) in 72\% yield. ${ }^{1} \mathrm{H} \mathrm{NMR}\left(300 \mathrm{MHz}, \mathrm{CD}_{2} \mathrm{Cl}_{2}, \mathrm{ppm}\right): \delta 6.39(\mathrm{dd}, \mathrm{J}=$ $17.1 \mathrm{~Hz}, \mathrm{~J}=1.2 \mathrm{~Hz}, 2 \mathrm{H}), 6.14(\mathrm{dd}, \mathrm{J}=17.3 \mathrm{~Hz}, \mathrm{~J}=10.5 \mathrm{~Hz}, 2 \mathrm{H}), 5.88-5.75(\mathrm{~m}, 1 \mathrm{H}), 5.85(\mathrm{dd}, \mathrm{J}$ $=10.5 \mathrm{~Hz}, \mathrm{~J}=1.2 \mathrm{~Hz}, 2 \mathrm{H}), 5.02-4.89(\mathrm{~m}, 2 \mathrm{H}), 4.23(\mathrm{~m}, 4 \mathrm{H}), 3.77$ (quintet, $\mathrm{J}=5.3 \mathrm{~Hz}, 1 \mathrm{H}), 3.56$ $(\mathrm{t}, \mathrm{J}=6.6 \mathrm{~Hz}, 2 \mathrm{H}), 2.03(\mathrm{~m}, 2 \mathrm{H}), 1.54(\mathrm{~m}, 2 \mathrm{H}), 1.32(\mathrm{~m}, 6 \mathrm{H}) .{ }^{13} \mathrm{C} \mathrm{NMR}\left(300 \mathrm{MHz}, \mathrm{CD}_{2} \mathrm{Cl}_{2}\right.$, ppm): $\delta 166.22,139.74,131.46,128.65,114.43,75.70,71.14,63.88,34.26,30.41,29.44,26.37$. $\operatorname{HRMS}(\mathrm{FAB}+) m / z: 311.1855[\mathrm{M}+\mathrm{H}]^{+}$. 

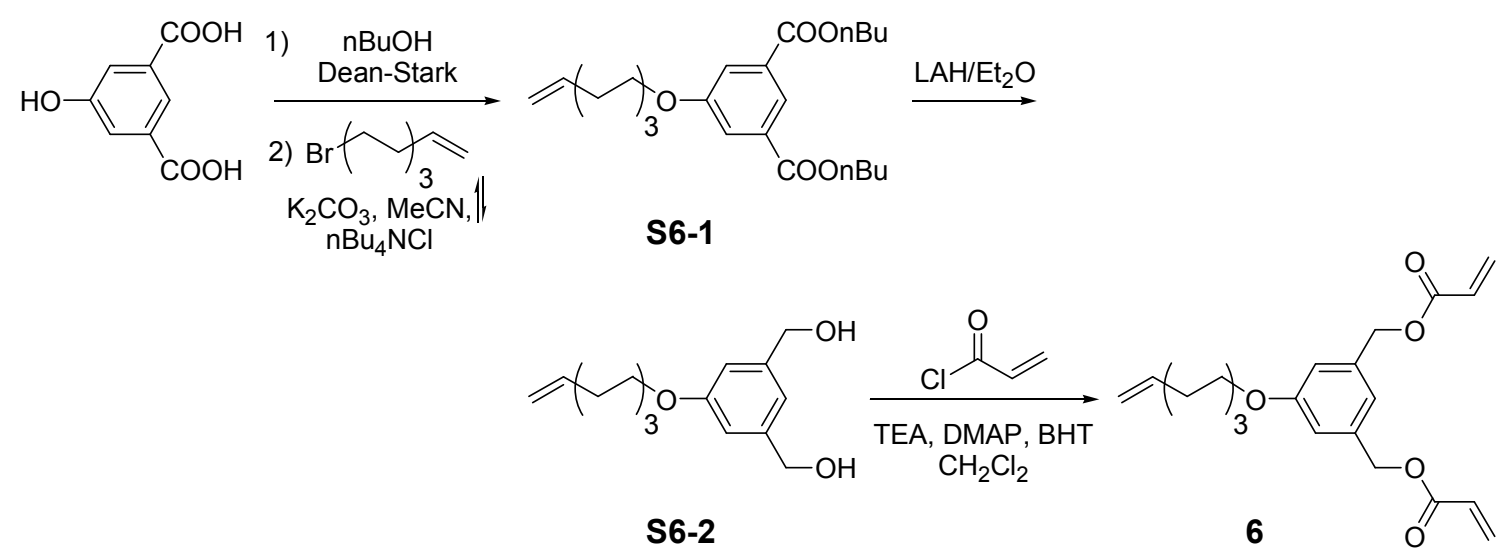

Scheme S4. Synthesis of monomer 6.

(6). 5-Hydroxyisophthalic acid (5.46 g, $30 \mathrm{mmol})$ was combined with n-butyl alcohol (10 $\mathrm{mL})$, benzene $(10 \mathrm{~mL})$, and p-toluenesulfonic acid monohydrate $(57 \mathrm{mg}, 0.3 \mathrm{mmol})$ in a $50 \mathrm{~mL}$ round bottom flask which was equipped with a Dean-Stark trap and a reflux condenser (Scheme S4). The reaction was refluxed until the white suspension in the reaction flask completely dissolved and no more water could be collected $(12 \mathrm{~h})$. The reaction solution was then concentrated under reduced pressure and dried under high vacuum for an additional $6 \mathrm{~h}$. The very thick, yellow residue obtained $(1.5 \mathrm{~g}, 5 \mathrm{mmol})$ was redissolved in $\mathrm{MeCN}(7 \mathrm{~mL})$ before being combined with 7-bromo-octene $(1 \mathrm{~mL}, 5.35 \mathrm{mmol})$, potassium carbonate $(1.17 \mathrm{~g}, 8.46$ mmol) and a catalytic amount of tetra-n-butylammonium chloride; this reaction was refluxed for $10 \mathrm{~h}$. The mixture was then cooled to room temperature, filtered, concentrated, and purified by silica gel chromatography. Eluting with 95:5 hexane:EtOAc afforded S6-1 (Scheme S4) in quantitative yield. NMR (300MHz, $\left.\mathrm{CD}_{2} \mathrm{Cl}_{2}, \mathrm{ppm}\right): \delta 8.21(\mathrm{t}, \mathrm{J}=1.5 \mathrm{~Hz}, 1 \mathrm{H}), 7.72(\mathrm{~d}, \mathrm{~J}=1.5 \mathrm{~J}$, 2H), $5.83(\mathrm{~m}, 1 \mathrm{H}), 5.04-4.91(\mathrm{~m}, 2 \mathrm{H}), 4.32(\mathrm{t}, \mathrm{J}=6.8 \mathrm{~Hz}, 4 \mathrm{H}), 4.05(\mathrm{t}, \mathrm{J}=6.6 \mathrm{~Hz}, 2 \mathrm{H}), 2.07(\mathrm{~m}$, 2H), $1.77(\mathrm{~m}, 6 \mathrm{H}), 1.55-1.37(\mathrm{~m}, 10 \mathrm{H}), 0.99(\mathrm{t}, \mathrm{J}=7.4 \mathrm{~Hz}, 6 \mathrm{H}) .{ }^{13} \mathrm{C} \mathrm{NMR}\left(300 \mathrm{MHz}, \mathrm{CD}_{2} \mathrm{Cl}_{2}\right.$, 
ppm): $\delta 166.16,159.80,139.66,132.75,122.90,119.96,114.55,69.17,65.74,34.26,31.27$, 29.61, 29.40, 29.37, 26.35, 19.84, 14.11. $\operatorname{HRMS}(\mathrm{FAB}+) m / z: 405.2645[\mathrm{M}+\mathrm{H}]^{+}$.

S6-1 (2.06 g, $5.1 \mathrm{mmol})$ was added to a stirring 1M solution of LAH in ethyl ether (11 $\mathrm{mL}$ ) at $0^{\circ} \mathrm{C}$; the mixture was allowed to slowly warm up to room temperature, before being heated to reflux. After 6 hours, the reaction was cooled to room temperature, and sodium sulfate decahydrate was slowly added to the reaction mixture with vigorous stirring until fizzing had ceased. The suspension was then stirred for $0.5 \mathrm{~h}$, filtered on Celite (the filter was washed with $\mathrm{Et}_{2} \mathrm{O}$ and boiling hot THF), and concentrated under reduced pressure. Obtained S6-2 was further purified by recrystallization from EtOH/hexane to afford $1.27 \mathrm{~g}$ (94\% yield) of a white solid. ${ }^{1} \mathrm{H}$ NMR (300MHz, $\left.\mathrm{CD}_{2} \mathrm{Cl}_{2}, \mathrm{ppm}\right): \delta 6.89(\mathrm{~s}, 1 \mathrm{H}), 6.80(\mathrm{~s}, 2 \mathrm{H}), 5.83(\mathrm{~m}, 1 \mathrm{H}), 5.03-4.90(\mathrm{~m}, 2 \mathrm{H})$, $4.61(\mathrm{~s}, 4 \mathrm{H}), 3.96(\mathrm{t}, \mathrm{J}=6.6 \mathrm{~Hz}, 2 \mathrm{H}), 2.05(\mathrm{~m}, 2 \mathrm{H}), 1.77(\mathrm{~m}, 2 \mathrm{H}), 1.64($ broad s, 2H; OH), 1.40 (m, 6H). ${ }^{13} \mathrm{C}$ NMR (300MHz, $\left.\mathrm{CDCl}_{3}, \mathrm{ppm}\right): \delta 160.12,143.55,139.18,117.64,114.49,112.35$, 68.55, 65.42, 34.25, 29.75, 29.40, 26.40. $\operatorname{HRMS}(\mathrm{FAB}+) \mathrm{m} / z: 264.1723[\mathrm{M}]^{+\bullet}$.

Colorless viscous oil $\mathbf{6}$ was made from S6-2 according to the standard procedure outlined for 2. ${ }^{1} \mathrm{H}$ NMR $\left(300 \mathrm{MHz}, \mathrm{CD}_{2} \mathrm{Cl}_{2}, \mathrm{ppm}\right): \delta 6.95(\mathrm{~s}, 1 \mathrm{H}), 6.87(\mathrm{~s}, 2 \mathrm{H}), 6.43(\mathrm{dd}, \mathrm{J}=17.6 \mathrm{~Hz}, \mathrm{~J}=$ $1.4 \mathrm{~Hz}, 2 \mathrm{H}), 6.18(\mathrm{dd}, \mathrm{J}=17.6 \mathrm{~Hz}, \mathrm{~J}=10.5 \mathrm{~Hz}, 2 \mathrm{H}), 5.90-5.77$ (m, 1H), 5.87 (dd, J = 10.5 Hz, J $=1.4 \mathrm{~Hz}, 2 \mathrm{H}), 5.15(\mathrm{~s}, 4 \mathrm{H}), 5.05-4.91(\mathrm{~m}, 2 \mathrm{H}), 3.97(\mathrm{t}, \mathrm{J}=6.6 \mathrm{~Hz}, 2 \mathrm{H}), 2.11-2.04(\mathrm{~m}, 2 \mathrm{H}), 1.83-$ $1.73(\mathrm{~m}, 2 \mathrm{H}), 1.52-1.35(\mathrm{~m}, 6 \mathrm{H}) .{ }^{13} \mathrm{C} \mathrm{NMR}\left(300 \mathrm{MHz}, \mathrm{CD}_{2} \mathrm{Cl}_{2}, \mathrm{ppm}\right): \delta 166.28,160.10,139.68$, 138.44, 131.47, 128.79, 120.04, 114.54, 114.32, 68.66, 66.41, 34.27, 29.71, 29.41, 26.40. HRMS(EI+) $m / z: 372.1924[\mathrm{M}]^{\bullet}$. 


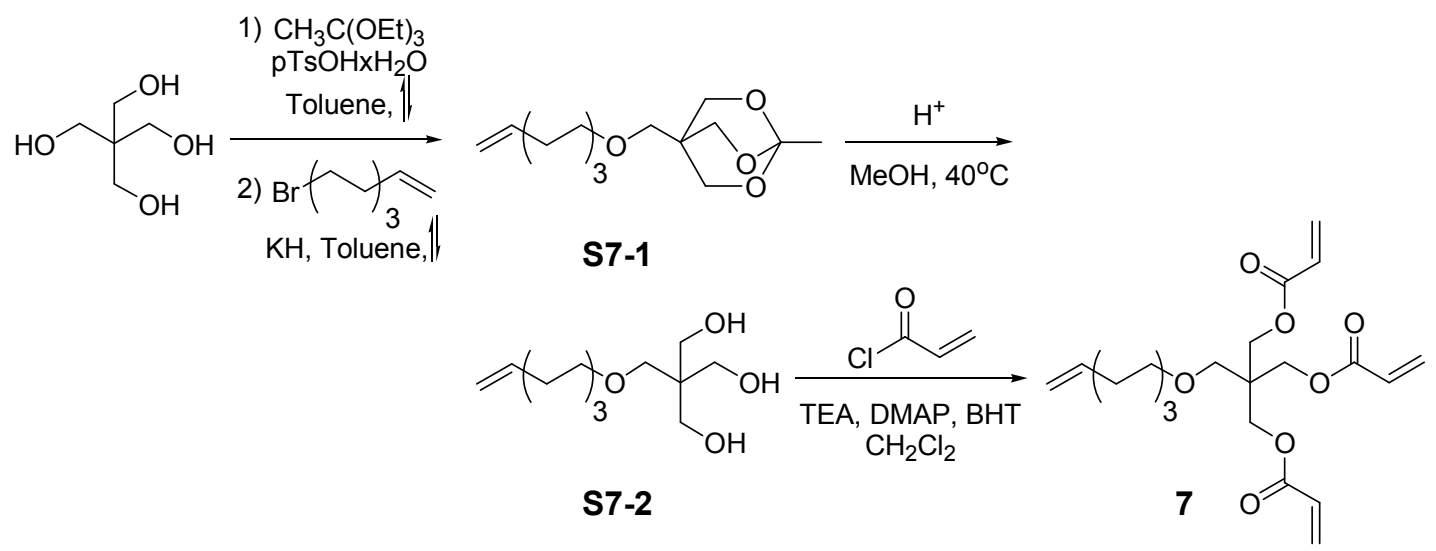

Scheme S5. Synthesis of monomer 7.

(7). Pentaerythritol (2 g, $14.7 \mathrm{mmol}$.) and p-toluenesulfonic acid monohydrate (28 mg, $0.15 \mathrm{mmol}$ ) were combined in $25 \mathrm{~mL}$ of dry toluene and heated to reflux (Scheme S5). Triethyl orthoacetate $(2.7 \mathrm{~mL}, 14.7 \mathrm{mmol})$ was added to the flask, and the resulting suspension was refluxed until the solution went clear and no solid residue was visible (24-48 hours). A few drops of triethyl amine were added to the completed reaction, and the solution was filtered while still hot. The solution was concentrated under reduced pressure, and white, soft crystals were obtained (1.9 g, 80\% yield). This orthoacetate protected product $(11.7 \mathrm{mmol})$ was redissolved in hot dry toluene, and potassium hydride (35\% suspension in oil, $2 \mathrm{~g}, 17.6 \mathrm{mmol}$ ) was added to the reaction flask followed by 7-bromo-octene $(2.2 \mathrm{~mL}, 12.9 \mathrm{mmol})$. The reaction mixture was then heated to reflux. After 10 hours, the reaction was cooled to room temperature and unreacted potassium hydride was quenched with a small amount of $\mathrm{iPrOH}$. The solution was filtered and concentrated. (S7-1 could be purified at this stage by silica gel chromatography, eluting with 95:5 hexane:EtOAc. ${ }^{1} \mathrm{H}$ NMR (300MHz, $\left.\mathrm{CD}_{2} \mathrm{Cl}_{2}, \mathrm{ppm}\right): \delta 5.82(\mathrm{~m}, 1 \mathrm{H}), 5.03-4.90(\mathrm{~m}, 2 \mathrm{H}), 3.95$ $(\mathrm{s}, 6 \mathrm{H}), 3.32(\mathrm{t}, \mathrm{J}=6.5 \mathrm{~Hz}, 2 \mathrm{H}), 3.13(\mathrm{~s}, 2 \mathrm{H}), 2.04(\mathrm{~m}, 2 \mathrm{H}), 1.50(\mathrm{~m}, 2 \mathrm{H}), 1.40-1.27(\mathrm{~m}, 9 \mathrm{H})$. 
${ }^{13} \mathrm{C}$ NMR (300MHz, $\left.\mathrm{CD}_{2} \mathrm{Cl}_{2}, \mathrm{ppm}\right): \delta 139.73,114.49,108.91,72.35,70.07,69.58,35.44,34.27$, $29.88,29.42,26.43,23.91)$.

The crude S7-1 was redissolved in $5 \mathrm{~mL}$ of methanol, a few drops of hydrochloric acid were added, and the mixture was stirred at $40^{\circ} \mathrm{C}$ for $2 \mathrm{~h}$ (Scheme S5). The $\mathrm{pH}$ was made basic with $\mathrm{NaOH}$ before the solution was filtered, concentrated, and purified by silica gel chromatography. The product was eluted with 95:5 $\mathrm{CH}_{2} \mathrm{Cl}_{2}: \mathrm{MeOH}$ and $\mathbf{S 7 - 2}$ was obtained in $31 \%$ overall yield (in three steps from pentaerythritol). ${ }^{1} \mathrm{H} \mathrm{NMR}\left(300 \mathrm{MHz}, \mathrm{CD}_{2} \mathrm{Cl}_{2}, \mathrm{ppm}\right): \delta$ 5.89-5.75 (m, 1H), 5.03-4.90 (m, 2H), $3.65(\mathrm{~d}, \mathrm{~J}=5.7 \mathrm{~Hz}, 6 \mathrm{H}), 3.42(\mathrm{~s}, 2 \mathrm{H}), 3.41(\mathrm{t}, \mathrm{J}=6.3 \mathrm{~Hz}$, 2H), $2.76(\mathrm{t}, \mathrm{J}=5.7 \mathrm{~Hz}, 3 \mathrm{H} ; \mathrm{OH}), 2.08-2.00(\mathrm{~m}, 2 \mathrm{H}), 1.58-1.51(\mathrm{~m}, 2 \mathrm{H}), 1.41-1.29(\mathrm{~m}, 6 \mathrm{H}) .{ }^{13} \mathrm{C}$ NMR (300MHz, $\left.\mathrm{CD}_{2} \mathrm{Cl}_{2}, \mathrm{ppm}\right): \delta 139.72,114.47,73.88,72.54,65.07,45.30,34.24,29.98$, 29.41, 29.38, 26.48. $\operatorname{HRMS}(\mathrm{EI}+) m / z: 247.1898[\mathrm{M}+\mathrm{H}]^{+}$.

Clear viscous oil 7 was made from 7S-2 according to the typical procedure outlined for $\mathbf{2}$ in $57 \%$ yield. ${ }^{1} \mathrm{H}$ NMR $\left(300 \mathrm{MHz}, \mathrm{CD}_{2} \mathrm{Cl}_{2}, \mathrm{ppm}\right): \delta 6.37(\mathrm{dd}, \mathrm{J}=17.6 \mathrm{~Hz}, \mathrm{~J}=1.7 \mathrm{~Hz}, 3 \mathrm{H}), 6.11$ $(\mathrm{dd}, \mathrm{J}=17.6 \mathrm{~Hz}, \mathrm{~J}=10.5 \mathrm{~Hz}, 3 \mathrm{H}), 5.88-5.74(\mathrm{~m}, 1 \mathrm{H}), 5.84(\mathrm{dd}, \mathrm{J}=10.5 \mathrm{~Hz}, \mathrm{~J}=1.7 \mathrm{~Hz}, 3 \mathrm{H})$, 5.02-4.89 (m, 2H), $4.24(\mathrm{~s}, 6 \mathrm{H}), 3.46(\mathrm{~s}, 2 \mathrm{H}), 3.38(\mathrm{t}, \mathrm{J}=6.6 \mathrm{~Hz}, 2 \mathrm{H}), 2.06-1.99(\mathrm{~m}, 2 \mathrm{H}), 1.57-$ $1.47(\mathrm{~m}, 2 \mathrm{H}), 1.40-1.26(\mathrm{~m}, 6 \mathrm{H}) .{ }^{13} \mathrm{C} \mathrm{NMR}\left(300 \mathrm{MHz}, \mathrm{CD}_{2} \mathrm{Cl}_{2}, \mathrm{ppm}\right): \delta 166.08,139.73,131.39$, $128.60,114.45,72.19,69.47,63.64,43.42,34.27,29.91,29.41,29.40,26.44$. HRMS(EI+) $m / z$ : $408.2149[\mathrm{M}]^{+\bullet}$.

Representative Polymerization Procedure (4a). Monomer 4 (0.1 g, 0.4 mmol) was dissolved in dry $\mathrm{CH}_{2} \mathrm{Cl}_{2}(1 \mathrm{ml}, 0.4 \mathrm{M})$ under an argon atmosphere. Catalyst $\mathbf{1}(1.7 \mathrm{mg}, 2 \mu \mathrm{mol})$ was added to the reaction flask, and the solution was stirred at $45^{\circ} \mathrm{C}$ for $3-8$ days (see explanation below) with venting through a bubbler. Subsequently, the reaction was concentrated and the product was characterized by ${ }^{1} \mathrm{H}$ NMR spectroscopy and triple detector-SEC with no 
further purification. ${ }^{1} \mathrm{H} \mathrm{NMR}\left(300 \mathrm{MHz}, \mathrm{CD}_{2} \mathrm{Cl}_{2}, \mathrm{ppm}\right): \delta 6.95(\mathrm{dt}, \mathrm{J}=15.6 \mathrm{~Hz}, \mathrm{~J}=5.8 \mathrm{~Hz}, 1 \mathrm{H})$, $6.40(\mathrm{ddd}, \mathrm{J}=17.4 \mathrm{~Hz}, \mathrm{~J}=4.9 \mathrm{~Hz}, \mathrm{~J}=1.3 \mathrm{~Hz}, 1 \mathrm{H}), 6.11(\mathrm{~m}, 1 \mathrm{H}), 5.82(\mathrm{~m}, 2 \mathrm{H}), 5.20(\mathrm{~m}, 1 \mathrm{H})$, 4.35-4.17 (m, 2H), 2.2 (broad m, 2H), 1.67-1.38 (broad m, 6H).

Figure S1 demonstrates the progress of a typical polymerization as monitored by GPC. We have observed that longer polymerization times result in higher molecular weights. However, the length of the catalyst's lifetime in the reaction solution limits the effectiveness of prolonging the polymerization time past 3 days. Consequently, we have found that the best results are obtained when the total calculated amount of the catalyst is split into smaller portions, which are then added to the reaction vessel at about 2 to 3 day intervals. In figure S1, trace A corresponds to a progress of the polymerization at 3 days and $0.25 \%$ of mole equivalents of the catalyst, trace B corresponds to 2 more days with a fresh batch of $0.25 \%$ of mole equivalents of the catalyst, and trace $\mathrm{C}$ corresponds to 3 more days with yet another catalyst batch. The gradual peak shift to the left (from A to C) indicates an increase in polymer molecular weight. Moreover, the trace also becomes more narrow and uniform with time, signaling the narrowing of the PDI. Further optimization of polymerization conditions is currently underway.

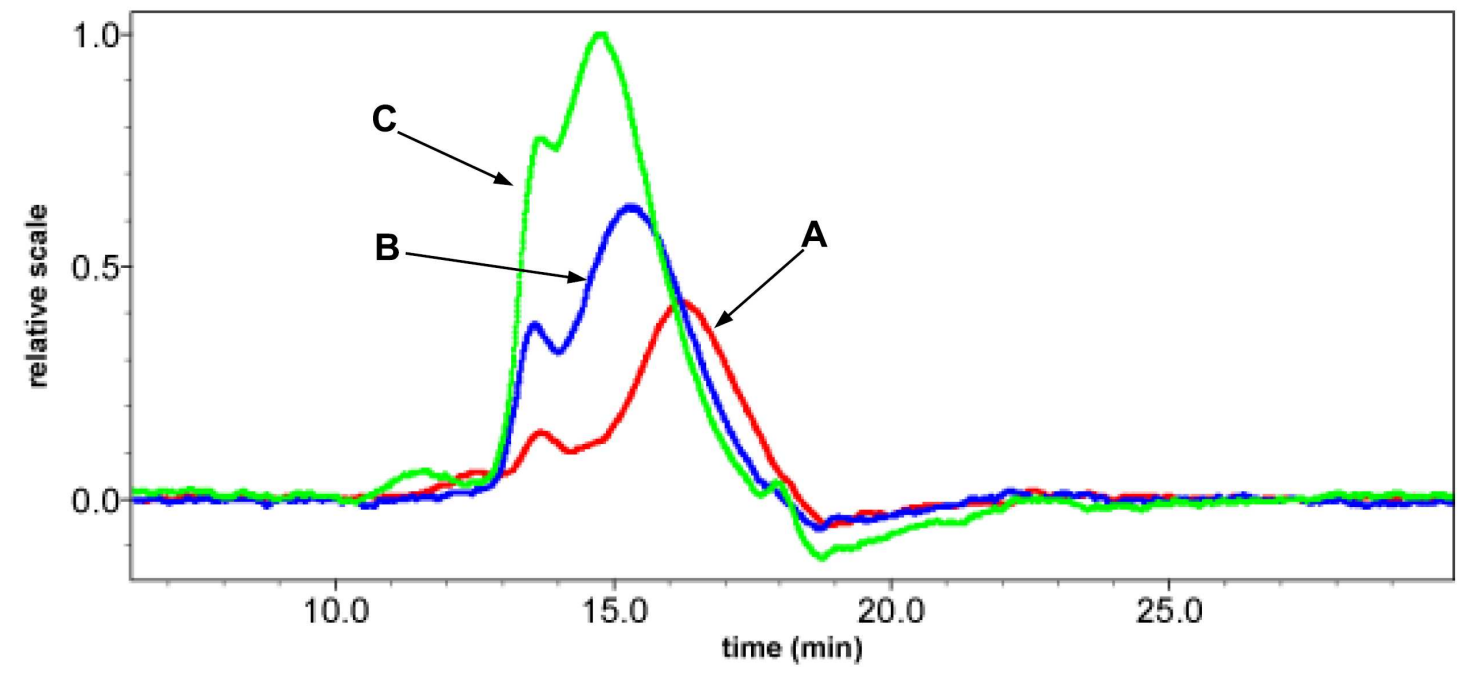

Figure S1. Representative MALS-SEC traces for polymerization of 4. 


\section{Detailed explanation of ${ }^{1} \mathrm{H}$ NMR spectra of 4 (Figure 1).}

If polymerization proceeds to completion, consuming all of the terminal aliphatic alkenes, there should be half of the free acrylate groups left in the final polymer. Since there are twice as many $\mathrm{B}$ groups as $\mathrm{A}$ groups in an $\mathrm{AB}_{2}$ monomer, an integration ratio of 1 (g) to 1 (c or d) should hold for the product of complete polymerization. Indeed, a 1:1 ratio is observed for $\mathbf{4 a}$, as well as 5a and 6a; it is 2:1 for 7a. Peaks d, c, and e completely disappear, along with the peaks for protons a, during the polymerizations of $\mathbf{2}$ and $\mathbf{3}$, and the integration ratio of the corresponding polymers' peaks $\mathbf{g}$ and $\mathbf{f}$ is $1: 1$. 